\title{
Effects of Vitamin $E$ on the Aggregation and the Lipid Peroxidation of Platelets Exposed to Hydrogen Peroxide
}

\author{
Ototaka Higashi and Yoko Kikuchi \\ Department of Pediatrics, Akita University School of Medicine, \\ Akita
}

HIGASH, O. and KIKUCH, Y. Effects of Vitamin E on the Aggregation and the Lipid Peroxidation of Platelets exposed to Hydrogen Peroxide. |Tohoku J. exp. Med., 1974, 112 (3), 271-278 — The hydrogen peroxide $\left(\mathrm{H}_{2} \mathrm{O}_{2}\right)$-induced platelet aggregation could be inhibited by vitamin E-nicotinate and less effectively by vitamin $\mathrm{E}$-acetate. The adenosine diphosphate (ADP)-induced platelet aggregation could be slightly inhibited by vitamin E-nicotinate. The lipid peroxidation of platelet exposed to $\mathrm{H}_{2} \mathrm{O}_{2}$ could also be inhibited by vitamin $\mathrm{E}$-nicotinate. The lipid peroxide formation associated with membrane disruption may be involved in the mechanism underlying the $\mathrm{H}_{2} \mathrm{O}_{2}$-induced platelet aggregation.

vitamin E-nicotinate; platelet aggregation; hydrogen peroxide; thrombosis; lipid peroxidation

In the preliminary paper of our own (Higashi and Kikuchi 1973), it was reported that vitamin $\mathrm{E}$ could inhibit, to some extent, the $\mathrm{H}_{2} \mathrm{O}_{2}$-induced platelet aggregation.

The present investigation was undertaken to extend further this study on the relationship between the vitamin $\mathrm{E}$ and $\mathrm{H}_{2} \mathrm{O}_{2}$-induced platelet aggregation.

\section{Materials and Methods}

Materials and methods are the same as described in the previous paper (Higashi et al. 1972, 1973), unless otherwise indicated.

$\alpha$-Naphthol and thymol were dissolved in ethanol to give the concentration of $58.3 \mathrm{mM}$.

In the experiment to test the effect of vitamin $\mathrm{E}$ on the platelet aggregation, vitamin $\mathrm{E}$ acetate and vitamin E-nicotinate (Eisai Co.) dissolved in ethanol were used as described previously (Higashi and Kikuchi 1973). But, in the experiment to examine the effect of vitamin $\mathrm{E}$ on the lipid peroxidation of platelets, vitamin E-nicotinate dissolved in polyoxyethylene(60)-hydrogenated castor oil (Eisai Co.) was used, as will be described in the present paper.

The hydrogen peroxide hemolysis test was performed by the method described by Horwitt et al., a modification of the original method of Rose et al. (Rose and György 1952; Horwitt et al. 1956).

Lipid peroxides in platelets were determined by the method described by Okuma et al. (1970), unless stated otherwise.

The platelet suspension was prepared as follows: $0.6 \mathrm{ml}$ of platelet-rich plasma (PRP) in siliconized test tube was centrifuged at $3,000 \mathrm{rpm}$ and $4^{\circ} \mathrm{C}$ for $30 \mathrm{~min}$. The supernatant was discarded and platelets were resuspended in $0.6 \mathrm{ml}$ of the imidazole buffer $\mathrm{pH} \quad 7.3$ (IBS). $0.003 \mathrm{ml}$ of approximately $93 \mathrm{mM}$ or $58 \mathrm{mM}$ vitamin E-nicotinate was added to $0.6 \mathrm{ml}$ of platelet suspension thus prepared. In two control tubes the same

Received for publication December 25, 1973. 
amount of solvent of the vitamin E-nicotinate preparation, which is polyoxyethylene(60)-hydrogenated castor oil, was added. The mixture was left at room temperature for one $\mathrm{hr}$. Then $0.027 \mathrm{ml}$ of IBS was added. After the incubation period of 1 min at $37^{\circ} \mathrm{C}$ in a water bath, $0.07 \mathrm{ml}$ of $0.3 \% \mathrm{H}_{2} \mathrm{O}_{2}$ was added to the experimental tubes and to one of the two control tubes. To another control tube left, $0.07 \mathrm{ml}$ of IBS was added. Tubes were shaken vigorously in the water bath for 1 minute. Then $0.7 \mathrm{ml}$ of the thiobarbituric acid (TBA) reagent was added. Then the mixture was heated in a boiling water bath for $10 \mathrm{~min}$. After the reaction mixtures had cooled to room temperature, $0.7 \mathrm{ml}$ of Biosolv (BBS-3) was added, and mixed on a Vortex mixer. Thereafter, $0.7 \mathrm{ml}$ of $1 \mathrm{~N} \mathrm{NaOH}$ was added, followed by further mixing until completely clear solution was obtained, as described by Okuma et al.(1970). Optical density at $548 \mathrm{~m} \mu$ was measured 3 min after the addition of Bio-solv.

For each one of control and experimental tubes, a blank tube, in which distilled water substituted for PRP, was provided. This was necessary, because even the content of a blank tube, which did not contain any platelet, developed a color when heated with TBA reagent, if it contained $\mathrm{H}_{2} \mathrm{O}_{2}$. The amount of malonaldehyde (MA) present in the sample was calculated by the formula described by Okuma et al. (1970).

To examine the effect of an increase of the osmotic pressure of external medium on the plate let aggregation, dextran, sodium chloride and sucrose were used. Dextran (molecular weight 61,500 ) was dissolved in IBS at the a concentration of $11.6 \mathrm{mM}$ and was added to PRP to give the final concentrations of 0.5 to $0.75 \mathrm{mM}$. Sodium chloride or sucrose was added as solid to PRP.

\section{Results}

\section{Effects of vitamin $E$-acetate and vitamin E-nicotinate on the platelet aggregation}

The $\mathrm{H}_{2} \mathrm{O}_{2}$-induced platelet aggregation was inhibited, to some extent, by both vitamin E-acetate and vitamin E-nicotinate at the final concentration of 0.1 to $0.25 \mathrm{mM}$. Vitamin E-nicotinate was more effective than vitamin E-acetate in suppressing the $\mathrm{H}_{2} \mathrm{O}_{2}$-induced platelet aggregation (Table 1 and Figs. 1 and 2).

The maximum level of the $\mathrm{H}_{2} \mathrm{O}_{2}$-induced platelet aggregation was descreased to about $60 \%$ of the original level by the preincubation of PRP with vitamin Enicotinate at the final concentration of $0.25 \mathrm{mM}$ at room temperature for one hr (Table 1 and Fig. 2).

The ADP-induced platelet aggregation, however, was not inhibited by vitamin E-acetate, and was slightly inhibited by vitamin E-nicotinate at the final concentration of 0.1 to $0.25 \mathrm{mM}$ (Table 2, Figs. 1 and 2).

The $\mathrm{H}_{2} \mathrm{O}_{2}$ hemolysis test revealed no abnormally increased hemolysis, indicating that individuals studied had no vitamin $\mathrm{E}$ deficiency.

Effects of a-naphthol and thymol on the platelet aggregation

The maximum aggregation of platelets induced by $\mathrm{H}_{2} \mathrm{O}_{2}$ was decreased to 90 to $80 \%$ of the original level by the preincubation of PRP with either $\alpha$-naphthol or thymol at the final concentration of $0.25 \mathrm{mM}$ at room temperature for one $\mathrm{hr}$.

The platelet aggregation induced by ADP, however, was not suppressed by these agents at the same concentration. 


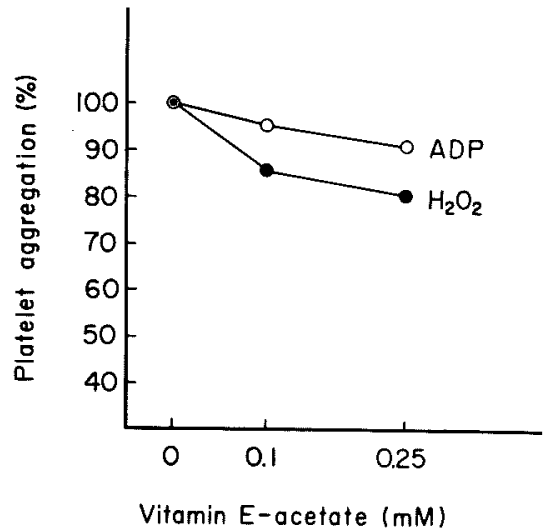

Fig. 1

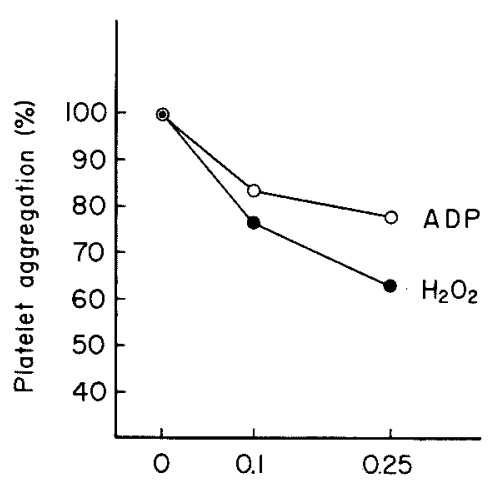

Vitamin E-nicotinate (mM)

Fig. 2

Fig. 1. Effects of vitamin E-acetate on the platelet aggregations induced by $\mathrm{H}_{2} \mathrm{O}_{2}(\bullet-\bullet)$ and by ADP (०-o). Mean values of 10 cases respectively. The values in this and the following figures are expressed in terms of percent of control values without vitamin E.

Fig. 2. Effects of vitamin E-nicotinate on the platelet aggregations induced by $\mathrm{H}_{2} \mathrm{O}_{2}(\bullet-\bullet)$ and by ADP (०-०). Mean values of 10 cases respectively.

TABLE 1. Effects of vitamin $\mathrm{E}$-acetate and vitamin E-nicotinate on $\mathrm{H}_{2} \mathrm{O}_{2}$-induced platelet aggregation (Maximum aggregation in percentage)

\begin{tabular}{|c|c|c|c|c|c|c|}
\hline \multirow{2}{*}{$\begin{array}{l}\text { Case } \\
\text { No. }\end{array}$} & \multirow{2}{*}{ IBS } & \multirow{2}{*}{ Ethanol } & \multicolumn{2}{|c|}{ Vitamin E-acetate } & \multicolumn{2}{|c|}{ Vitamin E-nicotiante } \\
\hline & & & $0.1 \mathrm{mM}$ & $0.25 \mathrm{mM}$ & $0.1 \mathrm{mM}$ & $0.25 \mathrm{mM}$ \\
\hline 1 & $45 \%$ & $\begin{array}{r}47 \% \\
(100)\end{array}$ & $\begin{array}{r}35 \% \\
(74)\end{array}$ & $\begin{array}{l}38 \% \\
(81)\end{array}$ & $\begin{array}{l}35 \% \\
(74)\end{array}$ & $\begin{array}{l}29 \% \\
(62)\end{array}$ \\
\hline 2 & $50 \%$ & $\begin{array}{r}44 \% \\
(100)\end{array}$ & $\begin{array}{r}44 \% \\
(100)\end{array}$ & $\begin{array}{l}41 \% \\
(91)\end{array}$ & $\begin{array}{l}39 \% \\
(89)\end{array}$ & $\begin{array}{l}32 \% \\
(73)\end{array}$ \\
\hline 3 & $55 \%$ & $\begin{array}{r}56 \% \\
(100)\end{array}$ & $\begin{array}{r}50 \% \\
(89)\end{array}$ & $\begin{array}{l}52 \% \\
(92)\end{array}$ & $\begin{array}{l}48 \% \\
(85)\end{array}$ & $\begin{array}{l}32 \% \\
(57)\end{array}$ \\
\hline 4 & $51 \%$ & $\begin{array}{r}50 \% \\
(100)\end{array}$ & $\begin{array}{r}40 \% \\
(80)\end{array}$ & $\begin{array}{l}40 \% \\
(80)\end{array}$ & $\begin{array}{l}37 \% \\
(74)\end{array}$ & $\begin{array}{r}34 \% \\
(68)\end{array}$ \\
\hline 5 & $40 \%$ & $\begin{array}{r}37 \% \\
(100)\end{array}$ & $\begin{array}{r}26 \% \\
(70)\end{array}$ & $\begin{array}{l}29 \% \\
(78)\end{array}$ & $\begin{array}{r}26 \% \\
(70)\end{array}$ & $\begin{array}{l}20 \% \\
(54)\end{array}$ \\
\hline 6 & $63 \%$ & $\begin{array}{r}62 \% \\
(100)\end{array}$ & $\begin{array}{r}61 \% \\
(98)\end{array}$ & $\begin{array}{l}57 \% \\
(92)\end{array}$ & $\begin{array}{l}48 \% \\
(77)\end{array}$ & $\begin{array}{l}46 \% \\
(74)\end{array}$ \\
\hline 7 & $46 \%$ & $\begin{array}{r}41 \% \\
(100)\end{array}$ & $\begin{array}{r}34 \% \\
(82)\end{array}$ & $\begin{array}{l}22 \% \\
(53)\end{array}$ & $\begin{array}{l}37 \% \\
(90)\end{array}$ & $\begin{array}{l}31 \% \\
(75)\end{array}$ \\
\hline 8 & $68 \%$ & $\begin{array}{r}61 \% \\
(100)\end{array}$ & $\begin{array}{r}57 \% \\
(93)\end{array}$ & $\begin{array}{l}55 \% \\
(90)\end{array}$ & $\begin{array}{l}50 \% \\
(82)\end{array}$ & $\begin{array}{l}35 \% \\
(57)\end{array}$ \\
\hline 9 & $40 \%$ & $\begin{array}{r}41 \% \\
(100)\end{array}$ & $\begin{array}{r}35 \% \\
(85)\end{array}$ & $\begin{array}{l}32 \% \\
(78)\end{array}$ & $\begin{array}{l}26 \% \\
(63)\end{array}$ & $\begin{array}{l}26 \% \\
(63)\end{array}$ \\
\hline 10 & $52 \%$ & $\begin{array}{r}49 \% \\
(100)\end{array}$ & $\begin{array}{r}47 \% \\
(95)\end{array}$ & $\begin{array}{l}39 \% \\
(79)\end{array}$ & $\begin{array}{l}34 \% \\
(69)\end{array}$ & $\begin{array}{l}25 \% \\
(51)\end{array}$ \\
\hline $\mathrm{Me}$ & S.D. & $(100 \pm 0)$ & $(86.6 \pm 9.7)$ & $(81.4 \pm 11.7)$ & $(77.3 \pm 9.2)$ & $(63.4 \pm 9.8)$ \\
\hline
\end{tabular}

* The numbers in parentheses refer to the percentage compared to the control value. 
TABLE 2. Effects of vitamin E-acetate and vitamin E-nicotinate on ADP-induced platelet aggregation (Maximum aggregation in percentage)

\begin{tabular}{|c|c|c|c|c|c|c|}
\hline \multirow{2}{*}{$\begin{array}{l}\text { Case } \\
\text { No. }\end{array}$} & \multirow{2}{*}{ IBS } & \multirow{2}{*}{ Ethanol } & \multicolumn{2}{|c|}{ Vitamin E-acetate } & \multicolumn{2}{|c|}{ Vitamin E-nicotinate } \\
\hline & & & $0.1 \mathrm{mM}$ & $0.25 \mathrm{mM}$ & $0.1 \mathrm{mM}$ & $0.25 \mathrm{mM}$ \\
\hline 1 & $57 \%$ & $\begin{array}{r}5896 \\
(100)\end{array}$ & $\begin{array}{c}54 \% \\
(93)^{*}\end{array}$ & $\begin{array}{l}52 \% \\
(90)\end{array}$ & $\begin{array}{l}46 \% \\
(79)\end{array}$ & $\begin{array}{l}45 \% \\
(78)\end{array}$ \\
\hline 2 & $76 \%$ & $\begin{array}{r}76 \% \\
(100)\end{array}$ & $\begin{array}{c}77 \% \\
(101)\end{array}$ & $\begin{array}{l}72 \% \\
(95)\end{array}$ & $\begin{array}{r}649 \\
(84)\end{array}$ & $\begin{array}{l}5996 \\
(78)\end{array}$ \\
\hline 3 & $66 \%$ & $\begin{array}{r}66 \% \\
(100)\end{array}$ & $\begin{array}{r}65 \% \\
(98)\end{array}$ & $\begin{array}{l}60 \% \\
(91)\end{array}$ & $\begin{array}{l}60 \% \\
(91)\end{array}$ & $\begin{array}{l}55 \% \\
(85)\end{array}$ \\
\hline 4 & $79 \%$ & $\begin{array}{r}72 \% \\
(100)\end{array}$ & $\begin{array}{r}7196 \\
(99)\end{array}$ & $\begin{array}{c}66 \% \\
(92)\end{array}$ & $\begin{array}{l}62 \% \\
(85)\end{array}$ & $\begin{array}{l}59 \% \\
(82)\end{array}$ \\
\hline 5 & $78 \%$ & $\begin{array}{r}78 \% \\
(100)\end{array}$ & $\begin{array}{r}73 \% \\
(94)\end{array}$ & $\begin{array}{l}70 \% \\
(90)\end{array}$ & $\begin{array}{l}6496 \\
(82)\end{array}$ & $\begin{array}{r}52 \% \\
(67)\end{array}$ \\
\hline \multirow[t]{2}{*}{6} & $73 \%$ & $\begin{array}{r}7296 \\
(100)\end{array}$ & $\begin{array}{r}68 \% \\
(94)\end{array}$ & $\begin{array}{l}59 \% \\
(81)\end{array}$ & $\begin{array}{r}62 \% \\
(86)\end{array}$ & $\begin{array}{l}54 \% \\
(75)\end{array}$ \\
\hline & $78 \%$ & $\begin{array}{r}70 \% \\
(100)\end{array}$ & $\begin{array}{r}66 \% \\
(94)\end{array}$ & $\begin{array}{l}62 \% \\
(89)\end{array}$ & $\begin{array}{r}56 \% \\
(80)\end{array}$ & $\begin{array}{l}61 \% \\
(87)\end{array}$ \\
\hline 8 & $64 \%$ & $\begin{array}{r}6796 \\
(100)\end{array}$ & $\begin{array}{r}6496 \\
(96)\end{array}$ & $\begin{array}{l}60 \% \\
(89)\end{array}$ & $\begin{array}{l}58 \% \\
(86)\end{array}$ & $\begin{array}{c}50 \% \\
(75)\end{array}$ \\
\hline 9 & $76 \%$ & $\begin{array}{r}76 \% \\
(100)\end{array}$ & $\begin{array}{r}63 \% \\
(83)\end{array}$ & $\begin{array}{l}7196 \\
(93)\end{array}$ & $\begin{array}{r}57 \% \\
(75)\end{array}$ & $\begin{array}{l}5496 \\
(71)\end{array}$ \\
\hline 10 & $78 \%$ & $\begin{array}{r}72 \% \\
(100)\end{array}$ & $\begin{array}{r}72 \% \\
(100)\end{array}$ & $\begin{array}{r}72 \% \\
(100)\end{array}$ & $\begin{array}{r}57 \% \\
(79)\end{array}$ & $\begin{array}{l}57 \% \\
(79)\end{array}$ \\
\hline \multicolumn{2}{|c|}{ Mean \pm S.D. } & $(100 \pm 0)$ & $(95.2 \pm 5.5)$ & $(91.0 \pm 5.2)$ & $(82.7 \pm 4.9)$ & $(77.7 \pm 5.8)$ \\
\hline
\end{tabular}

* The numbers in parentheses refer to the percentage compared to the control value.

\section{Effects of vitamin E-nicotinate on the lipid peroxidation of platelets}

The amount of lipid peroxide break down products as measured by the TBA reaction was decreased by the preincubation of platelet suspension with vitamin E-nicotinate at a final concentration ranging from 0.25 to $0.4 \mathrm{mM}$, as shown in Table 3 and Fig. 3.

Effects of sodium chloride, dextran and sucrose on the platelet aggregation

The effect of an increase of osmotic pressure of the external medium on the platelet aggregation was different depending on the kind of substances added and their concentration.

Both the $\mathrm{H}_{2} \mathrm{O}_{2}$-induced and the ADP-induced platelet aggregations were inhibited by sodium chloride added at the final concentration of $150 \mathrm{mM}$.

Dextran (molecular weight 61,500) had a minimal effect on both the $\mathrm{H}_{2} \mathrm{O}_{2}$ induced and the ADP-induced platelet aggregations when added at the final concentration of 0.5 to $0.75 \mathrm{mM}$.

Sucrose, at the final concentration of $100 \mathrm{mM}$, had a marked inhibitory effect upon the $\mathrm{H}_{2} \mathrm{O}_{2}$-induced platelet aggregation, while it had no effect on the ADPinduced platelet aggregation (Fig. 4). 


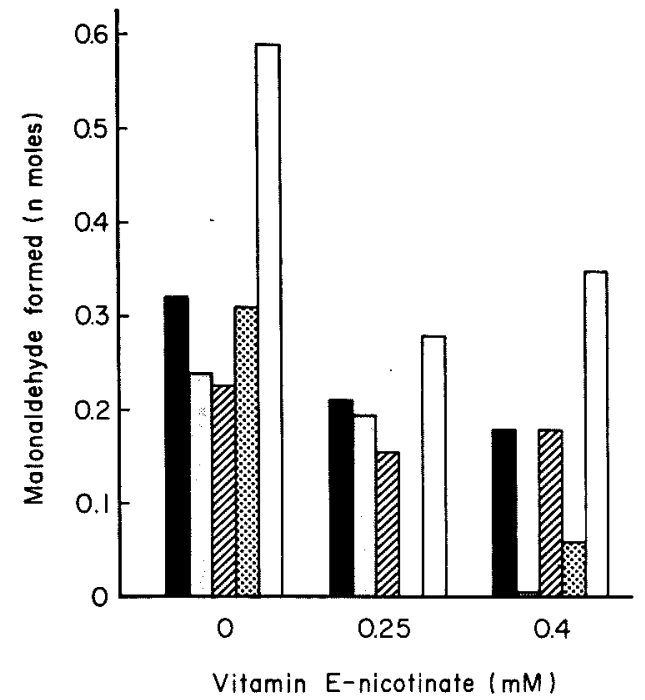

Fig. 3

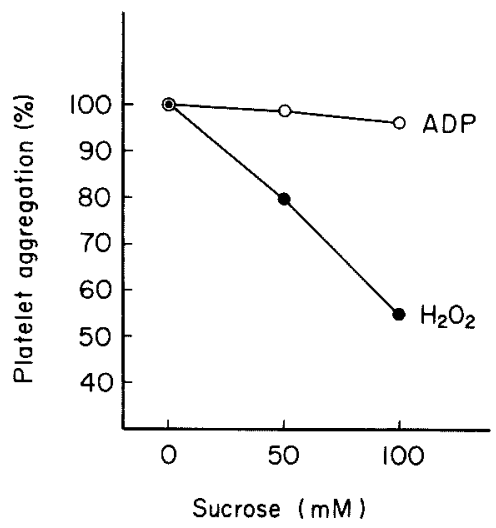

Fig. 4

Fig. 3. Inhibitory effects of vitamin E-nicotinate on the lipid peroxidation of platelets (cf. Table 3).

Fig. 4. Effects of sucrose on the platelet aggregations induced by $\mathrm{H}_{2} \mathrm{O}_{2}(\bullet-\bullet)$ and by ADP $(0-0)$. Mean values of five cases respectively. The values are expressed in terms of percent of control values without sucrose.

TABLE 3. Effect of vitamin E-nicotinate on the lipid peroxidation of platelets exposed to $\mathrm{H}_{2} \mathrm{O}_{2}$

\begin{tabular}{ccccc} 
& & \multicolumn{3}{c}{ Malonaldehyde (nmoles) } \\
\cline { 3 - 5 } $\begin{array}{c}\text { Case } \\
\text { No. }\end{array}$ & $\begin{array}{c}\text { Total platelet } \\
\text { count in each } \\
\text { tube }\end{array}$ & Placebo & \multicolumn{2}{c}{$\begin{array}{c}\text { Approximate final concentrations } \\
\text { of vitamin E-nicotinate }\end{array}$} \\
\cline { 4 - 5 } & & & $0.25 \mathrm{mM}$ & $0.4 \mathrm{mM}$ \\
\hline 1 & $1.32 \times 10^{8}$ & 0.322 & 0.210 & 0.182 \\
2 & $1.86 \times 10^{8}$ & 0.238 & 0.196 & 0.014 \\
3 & $2.16 \times 10^{8}$ & 0.226 & 0.154 & 0.182 \\
4 & $1.98 \times 10^{8}$ & 0.308 & 0 & 0.056 \\
5 & $2.16 \times 10^{8}$ & 0.588 & 0.280 & 0.350 \\
\hline
\end{tabular}

\section{Discussion}

The phenomenon of platelet aggregation may play a critical role in the early stage of hemostasis and/or thrombosis (Owren 1965; Born 1972). As reported previously, platelets can be aggregated by $\mathrm{H}_{2} \mathrm{O}_{2}$ in vitro (Higashi et al. 1972).

$\mathrm{H}_{2} \mathrm{O}_{2}$ can be produced in an excess in normal polymorphonuclear leukocytes during phagocytosis and be released and may act on glucose-6-phosphate dehydrogenase-deficient erythrocytes as an oxidant stress to cause a decrease of the reduced glutathione level and hemolysis, as demonstrated by Baehner et al. (1971).

It seems reasonable, therefore, to speculate that the $\mathrm{H}_{2} \mathrm{O}_{2}$-induced platelet aggrgation might occur not only in vitro but also in vivo, i.e., in areas of local 
infection or inflammation where there is an accumulation of polymorphonuclear leukocytes.

As confirmed in the present investigation, vitamin E-acetate and vitamin $\mathrm{E}$ nicotinate, especially the latter, can inhibit the $\mathrm{H}_{2} \mathrm{O}_{2}$-induced platelet aggregation to some extent. The ADP-induced platelet aggregation was slightly inhibited by vitamin E-nicotinate. Kurokawa et al. (1971) demonstrated that $\alpha$-tocopheryl acetate and $\alpha$-tocopheryl acetophosphate could inhibit the ADP-induced platelet aggregation. The mechanism of inhibition by vitamin $\mathrm{E}$ derivatives on the ADPinduced platelet aggregation has been unknown. According to Okuma et al. (1971) ADP alone does not increase the lipid peroxide formation of platelets. As shown in the present investigation, the ADP-induced platelet aggregation was not inhibited by $\alpha$-naphthol and thymol, known as phenolic antioxidants.

On the contrary, the $\mathrm{H}_{2} \mathrm{O}_{2}$-induced platelet aggregation could be inhibited, although slight in degree, by $\alpha$-naphthol and thymol, as revealed by the present experiments. The lipid peroxidation of platelets exposed to $\mathrm{H}_{2} \mathrm{O}_{2}$ can also be suppressed by vitamin E-nicotinate as described above. These findings may suggest that vitamin $\mathrm{E}$ derivatives exerted their inhibitory effects on the $\mathrm{H}_{2} \mathrm{O}_{2}$-induced platelet aggregation by acting as the antioxidant. Lipid peroxidation may cause membrane disruption (Witting 1965). That the $\mathrm{H}_{2} \mathrm{O}_{2}$-induced platelet aggregation, but not the ADP-induced platelet aggregation, was inhibited by increasing the osmotic pressure of the external medium by adding sucrose as shown in the present study, may suggest that the permeability change and/or disruption of membrane associated with lipid peroxidation might be involved in the mechanism underlying the process of $\mathrm{H}_{2} \mathrm{O}_{2}$-induced platelet aggregation.

Younkin et al. (1971) have studied on the mechanism of the hydrogen peroxide hemolysis and its reversal with phenols. They have suggested that lipid peroxidation causes hemolysis through membrane damage resulting in colloid osmotic lysis, and that vitamin $\mathrm{E}$ prevents $\mathrm{H}_{2} \mathrm{O}_{2}$-induced hemolysis by acting as a phenolic antioxidant, which is capable of neutralizing free radicals and thereby terminates chain reaction-type lipid peroxidation. It, thus, appears that the similar, if not identical, mechanism may operate, as far as the process of membrane damage is concerned, in both the $\mathrm{H}_{2} \mathrm{O}_{2}$-induced platelet aggregation and the $\mathrm{H}_{2} \mathrm{O}_{2}$ induced hemolysis. In the case of platelets, however, the permeability change and/or disruption of membrane due to $\mathrm{H}_{2} \mathrm{O}_{2}$ might result in the release of ADP, which in turn cause the platelet aggregation, as suggested previously (Higashi et al. 1972).

In view of the important role of platelet aggregation in the development of occlusive vascular disease, it has been generally accepted that studies on the inhibitors of platelet aggregtion may have a potential value for the prevention of such a disease (Marcus 1969).

It is interesting to note in literatures that thrombosis was discovered in fetal rats dying in mothers which were vitamin $\mathrm{E}$ deficient (Mason 1943), and that the chicks fed on the vitamin E-deficient diet may develop cerebellar capillary 
thrombosis and encephalomalacia (Pappenheimer and Goettsch 1931, Wolf and Pappenheimer 1931). Also vitamin $\mathrm{E}$ has the antithrombic activity (Zierler et al. 1948). On the basis of these data of previous investigators and of our own, it may be suggested that vitamin $\mathrm{E}$ may play an important role in prevention of thrombosis and related conditions.

\section{Acknowledgment}

We are grateful to Dr. Gerald T. Keusch, Mount Sinai Hospital, New York, USA and Dr. Akira Wakisaka, Associate Professor, Department of Biochemistry, Akita University School of Medicine, Akita, for their helpful criticism and advice.

\section{References}

1) Baehner, R.L., Nathan, D.G. \& Castle, W.B. (1971) Oxidant injury of Caucasian glucose-6-phosphate dehydrogenase-deficient red blood cells by phagocytosing leukocytes during infection. J. clin. Invest., 50, 2466-2473.

2) Born, G.V.R. (1972) Platelets. Functional physiology. In: Human Blood C ragulation, Haemostasis and Thrombosis, edited by R. Biggs, Blackwell Scientific Publications, Oxford, pp. 159-175.

3) Higashi, O., Kikuchi, Y.\& Konno, K. (1972) A case of thrombasthenia with a study of platelet aggregation by hydrogen peroxide $\left(\mathrm{H}_{2} \mathrm{O}_{2}\right)$. Tohoku J. exp. Med., 106, 399409 .

4) Higashi, O., Kikuchi, Y. \& Konno, K. (1973) Effects of metabolio inhibitors on the platelet aggregation induced by hydrogen peroxide. Tohoku J. exp. Med., 109, 245250.

5) Higashi, O. \& Kikuchi, Y. (1973) In vitro effects of vitamin E on hydrogen peroxide -induced platelet aggregation. Tohoku J. exp. Med., 111, 99-100.

6) Horwitt, M.K., Harvey, C.C., Duncan, G.D. \& Wilson, W.C. (1956) Effects of limited tocopherol intake in man with relationship to erythrocyte hemolysis and lipid oxidations. Amer. J. clin. Nutr., 4, 408-419.

7) Kurokawa, I., Kimura, T., Nagai, T. \& Kamimura, M. (1971) The effect of vitamin $\mathrm{E}$ on the adenosine diphosphate induced platelet aggregation. J. Vitaminology, 17, 181-184.

8) Marcus, A.J. (1969) Platelet function (First of three parts). New Eng. J. Med., 280, 1213-1220.

9) Mason, K.E. (1943) Essays in Biology in Honor of Herbert M. Evans, IUniversity of California Press. P. 401. Cit. by K.L. Zierler, D. Grob and L.J. Lilienthal, Jr., in the Reference 18) of the present paper.

10) Okuma, M., Steiner, M. \& Baldini, M. (1970) Studies on lipid peroxides in platelets. I. Method of assay and effect of storage. J. Lab. clin. Med., 75, 283-296.

11) Okuma, M., Steiner, M. \& Baldini, M.G. (1971) Studies on lipid peroxides in platelets. II. Effect of aggregating agents and platelet antibody. J. Lab. clin. Med., 77, 728742.

12) Owren, P.A. (1965) Coronary thrombosis. Its mechanism and possible prevention by linolenic acid. Ann. intern. Med., 63, 167-184.

13) Pappenheimer, A.M. \& Goettsch, M. (1931) A cerebellar disorder in chicks, apparently of nutritional origin. J. exp. Med., 53, 11-26.

14) Rose, C.S. \& György, P. (1952) Specificity of hemolytic reaction in vitamin E-deficient erythrocytes. Amer. J. Physiol., 168, 414-420.

15) Witting, L.A. (1965) Lipid peroxidationin in vivo. J. Amer. Oil Chemist's Soc., 42, 908-913.

16) Wolf, A. \& Pappenheimer, A.M. (1931) The histopathology of nutrional encephalo- 
malacia of chicks. J. exp. Med., 54, 399-405.

17) Younkin, S., Oski, F.A. \& Barness, L.A. (1971) Mechanism of the hydrogen peroxide hemolysis test and its reversal with phenols. Amer. J. clin. Nutr., 24, 7-13.

18) Zierler, K.L., Grob, D. \& Lilienthal, J.L., Jr. (1948) On the antithrombic and antiproteolytic activity of alpha tocopheryl phosphate. Amer. J. Physiol., 153, 127-132. 